\title{
Penyuluhan dan pelatihan membuat tempat cuci dapur dan drainase rumah panggung di Desa Salobukkang
}

\author{
Panennungi T. ${ }^{1}$, Bakhrani A. Rauf ${ }^{2}$ \\ ${ }^{1,2}$ Fa kultas Teknik, Universitas Negeri Makassar
}

\begin{abstract}
This socialwork a imed to improve: (1) partner's knowledge kitchen wa shing place and d rainage (2) partner's skill to kitchen wa shing place and drainage and (3) the skill to make kitchen wa shing place and drainage. The methods that used of this social work were : (1) to improve the knowledge of people about the kitchen washing place and drainage of stilt house then the discourse, interactive and discussion method are conducted, (2) to improve their skill to design the kitchen washing place and drainage then methods discourse, interactive, disc ussion, a nd demonstration are conducted and (3) to improve the skill to make the kitchen wa shing place and drainage then discourse, interactive, discussion, demonstration, and training methods a re conducted. The results of social work, (1) the people was highly motivated to follow these activities; (2) the material of workshop was resp onded by people because of kitchen wa shing place and drainage of stilt house was easy to be made a nd the compound could be gained in workshop location; (3) kitchen wa shing place and drainage of stilt house could be accepted, un derstood, and followed by people technically; (4) the people were ready to make their own kitchen washing place and drainage construction in their house and inform to others.
\end{abstract}

Key words: kitchen wa shing place, drainage

\section{PENDAHULUAN}

Kecamatan Dua Pitue merupakan salah satu kecamatan yang ada di Kabupaten Sidenreng Rappang Propinsi Sulawesi Selatan; wilayah Kecamatan Dua Pitue meliputi beberapa desa. Salah satu diantaranya adalah Desa Salobukkang yang terletak di bagian utara wilayah kecamatan.

Jumlah penduduk Desa Salobukkang sebanyak 1543 orang dengan jumlah kepala keluarga 385 orang. Luas wilayah desa $12,35 \mathrm{~km} 2$, berada pada kondisi topografi yang relatif datar. Pada umumnya pekerjaan utama penduduk desa adalah bertani sawah dan berkebun.

Tingkat pendidikan masyarakat yang bermukim di Desa Salobukkang umumnya relatif rendah, yakni sekitar $80 \%$ masih berpendidikan sekolah dasar. Untuk itu, dapat dipahami bahwa pengetahuan keteknikan, kesehatan masyarakat, dan kesehatan lingkungan bagi mereka masih belum memadai.

Kelompok remaja yang tergolong usia remaja di Desa Salobukkang, terbilang cukup banyak. Pekerjaan merakapun masih mengikuti pekerjaan orang tuanya secara turun temurun, yakni bertani sawah dan berkebun. Waktu yang digunakan untuk bertani dalam satu musim secara efektif berkisar hanya 1 bulan; selebihnya sekitar 3 bulan tidak dimanfaatkan untuk kegiatan mencari pekerjaan lain untuk menambah pendapatan keluarga

Model tempat cuci dapur yang ada di rumah tempat tinggal penduduk yang bermukim di Desa Salobukkang. Sistem pembuangan air bekas cucian dari dapur masih dibiarkan terbuang begitu saja sehingga dapat menimbulkan kerusakan kayu bangunan rumah akibat terkena air. Selain itu timbul comberan di bawah kolong rumah yang kelihatan jorok dan lingkungan tidak sehat. Kondisi ini dapat diatasi dengan membuat tempat cuci dapur yang terbuat dari bahan beton dan drainase dari pipa untuk mengalirkan air bekas cucian ke saluran pembuang.

Kelompok remaja yang ada di desa Salobukkang, sebaiknya diarahkan pada kegiatan yang bersifat lebih produktif. Salah satu kegiatan pekerjaan tambahan yang dapat dilakukan adalah membuatkan setiap rumah penduduk tempat cuci dapur dan drainase, sehingga bila digunakan tidak lagi merusak bagian kayu bangunan rumah dan air 
bekas cucian mengalir ke saluran pembuang sehingga lingkungan menjadi sehat.

Wawancara yang dikakukan kepada Kepala Desa Salobukkang (Desember 2019), menyatakan bahwa sebenarnya kelompok remaja yang bermukim di Desa Salobukkang berkeinginan untuk membuat tempat cuci dapur dan drainase rumah panggung, hanya saja pengetahuan dan keterampilan teknik remaja di Desa Salobukkang masih sangat kurang.

Berdasarkan uraian di atas, maka perlu dan tepat sekali untuk dilakukan penyuluhan dan pelatihan pembuatan tempat cuci dapur dan drainase rumah panggung bagi kelompok remaja putus sekolah di Desa Salobukkang Kecamatan Dua Pitue Kabupaten Sidenreng Rappang.

Air buangan atau limbah (waste water) adalah air yang telah selesai digunakan oleh berbagai kegiatan manusia (rumah tangga, industri, bangunan umum, dan lain-lain). Dampak pembuangan air limbah terhadap lingkungan adalah timbulnya bau busuk, karena pencemaran yang tinggi sehingga air menjadi septik, menurunnya kualitas air tanah, dan menurunnya kaualitas kesehatan lingkungan. (Hartono Purbo, 1998).

Perilaku masyarakat seperti membiarkan air buangan cucian dapur secara bebas membentuk comberan dan sistem drainase air hujan yang tidak terarah, berakibat mutu hidup mereka sebagai sumber daya manusia rendah (Soerjani, 1987). Jika mutu hidup mereka rendah dalam suatu tata ruang lingkungan, akan mengakibatkan lingkungan mengalami degradasi (Soemarwoto, 1985).

Oleh karena itu, perilaku masyarakat yang kurang peduli kesehatan dan lingkungan ini perlu dibina sehingga melahirkan sumber daya manusia yang produktif dan berkelanjutan. Hal ini sejalan dengan pendapat yang dikemukakan oleh Tjiptoherijanto (1989) yang menyatakan sumber daya manusia perlu dilatih untuk mempersiapkan dirinya menjadi manusia yang produktif. Seperti juga halnya melatih mereka membuat tempat cuci dapur dan drainase yang memenuhi syarat teknis.

Perilaku manusia pada lingkungan alamiah akan menimbulkan masalah lingkungan. Selain itu, juga berdampak negatif terhadap dirinya (Sarwono,
1992). Perilaku itu seperti juga membuang air bekas cucian dapur secara bebas membentuk comberan yang tidak diarahkan ke saluran pembuangan yang tidak terarah ke saluran drainase jalan (Asrib \& Arfandi, 2019).

Berdasarkan uraian di atas, dapat dipahami bahwa kesehatan masyarakat sangat ditentukan oleh pengetahuan kesehatan yang dimilikinya, teknologi, keterampilan teknik yang dimiliki, dan lain-lain.

Salah satu teknologi tepat guna yang dapat meningkatkan mutu kesehatan masyarakat pedesaan yang lingkungan alaminya kurang memenuhi syarat kesehatan adalah membuat tempat cuci dapur dan drainase pada rumah masing-masing penduduk. Hal ini sangat memungkinkan dikerjakan oleh masyarakat karena biayanya relatif murah dan bahan yang digunakan tersedia di lokasi kegiatan.

Masalah pengabdian kepada masyarakat ini, adalah sebagai berikut: (1) mitra tidak memiliki pengetahuan tentang konstruksi tempat cuci dapur dan drainase, (2) mitra tidak memiliki keterampilan untuk mendesain konstruksi tempat cuci dapur dan drainase yang memenuhi syarat teknis, dan (3) mitra tidak memiliki keterampilan untuk membuat konstruksi tempat cuci dapur dan drainase.

Pengabdian kepada masyarakat ini bertujuan untuk: (1) meningkatkan pengetahuan mitra tentang konstruksi tempat cuci dapur dan drainase, (2) menigkatkan keterampilan masyarakat untuk mendesain konstruksi tempat cuci dapur dan drainase yang memenuhi syarat teknis, dan (3) meningkatkan keterampilan mitra untuk membuat konstruksi tempat cuci dapur dan drainase.

\section{METODE PELAKSANAAN}

Metode pendekatan yang dilakukan untuk menyelesaikan persoalan mitra yang telah disepakati bersama adalah sebagai berikut: (1) melakukan penyuluhan pengetahuan tentang konstruksi tempat cuci dapur dan drainase; metode yang dipakai adalah: ceramah, tanya-jawab, dan diskusi, (2) melakukan pelatihan keterampilan 
mendesain konstruksi tempat cuci dapur dan drainase yang memenuhi syarat teknis; metode yang dipakai adalah: ceramah, tanya-jawab, diskusi, dan latihan, dan (3) melakukan pelatihan membuat tempat cuci dapur dan drainase; metode yang dipakai adalah: ceramah, tanya-jawab, diskusi, dan latihan.

\section{HASIL DAN PEMBAHASAN}

Hasil Hasil yang dicapai dalam kegiatan Program Kemitraan Masyarakat Stimulus (PKMS) ini adalah sebagai berikut: (1) minat dan motivasi peserta (mitra) cukup tinggi atau antusias dalam mengikuti seluruh kegiatan yang diberikan oleh tim pelaksana kegiatan PKMS, (2) peserta telah memperoleh pengetahuan yang tinggi tentang konstruksi tempat cuci dapur dan drainase, (3) peserta telah memperoleh keterampilan yang tinggi untuk mendesain konstruksi tempat cuci dapur dan drainase, (5) peserta telah memperoleh keterampilan yang tinggi untuk membuat konstruksi tempat cuci dapur dan drainase.

Hasil yang dicapai seperti di atas ditunjukkan dalam bentuk gambar berupa produk/barang, sebagai berikut: Konstruksi tempat cuci dapur dan drainase. Spesifikasi konstruksi tempat cuci dapur dan drainase yang dihasilkan terdiri dari plat beton ukuran $1,50 \times 1,50 \mathrm{~m}$ tebal $0,08 \mathrm{~m}$ dilengkapi pembatas tepi keliling dari pasangan batu bata setinggi $0,15 \mathrm{~m}$, dilengkapi pipa pembuang vertikal berdiameter 3".

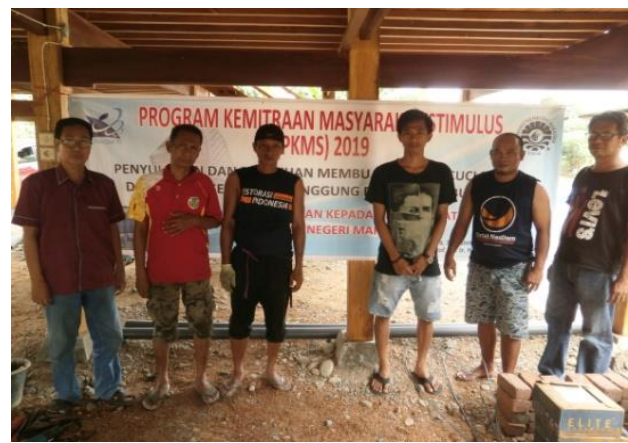

Gambar1. Mitra PKMS

Untuk melakukan kegiatan pelatihan keterampilan membuat tempat cuci dapur dan drainase sesuai dengan gambar desain yang dipersiapkan, maka dilakukan langkah-langkah kegiatan sebagai berikut: (1) mempersiapkan bahan yang akan digunakan, (2) mempersiapkan peralatan yang akan digunakan, (3) memberi penjelasan tentang gambar desain tempat cuci dapur dan drainase yang akan dikerjakan, (4) melakukan pekerjaan membuat tempat cuci dapur dan drainase bersama dengan mitra, (6) melakukan evaluasi hasil pekerjaan tempat cuci dapur dan drainase yang telah dikerjakan oleh mitra.

Evaluasi pelaksanaan program PKMS untuk mengukur pengetahuan dan keterampilan peserta (mitra) dilakukan sebagai berikut: (1) evaluasi pengetahuan meliputi: pengetahuan peserta tentang konsrruksi tempat cuci dapur dan drainase, (2) evaluasi keterampilan meliputi: keterampilan peserta untuk mendesain dan membuat tempat cuci dapur dan drainase sesuai dengan gambar desain yang diberikan.

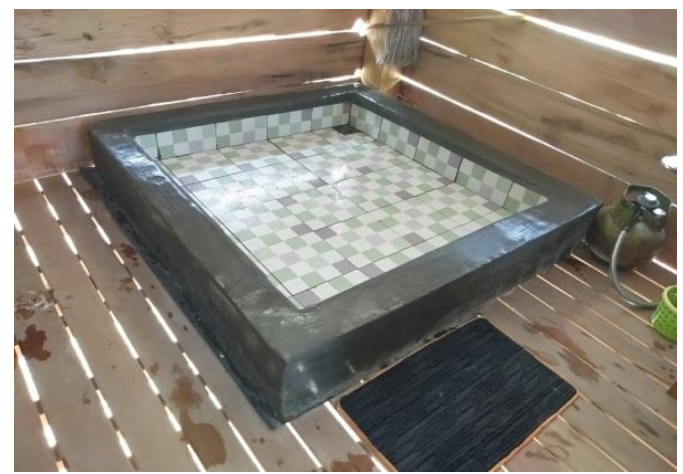

Gambar 2. Produk PKMS

Hasil evaluasi kegiatan menunjukkan bahwa mitra PKMS telah memiliki pengetahuan dan keterampilan yang tinggi untuk mendesain dan membuat tempat cuci dapur dan drainase rumah panggung.

Faktor pendukung terlaksananya kegiatan PKMS ini bersama dengan kedua mitra adalah sebagai berikut: (1) adanya kesediaan mitra untuk menyiapkan tempat dan peralatan untuk melaksanakan kegiatan, mengikuti penyuluhan dan pelatihan keterampilan, mengantar Tim Pelaksana Kegiatan untuk membeli bahan dan peralatan tambahan yang diperlukan di lokasi kegiatan, (2) ketersediaan toko bahan bangunan dan peralatan 
untuk membeli kebutuhan alat dan bahan untuk keperluan pelaksanan kegiatan PKMS, (3) minat dan motivasi peserta sangat tinggi, ditunjukkan dengan ketepatan waktu hadir dan frekuensi kehadiran selama kegiatan berlangsung, serta kesungguhan peserta dalam mendampingi dan berdiskusi dengan Tim Pelaksana PKMS untuk menyelesaikan persoalan yang dihadapi mitra, (4) dukungan dari pemerintah setempat, terutama dalam hal persuratan dan perizinan untuk melaksanakan kegiatan PKMS.

Faktor penghambat dalam pelaksanaan kegiatan PKMS ini adalah sebagai berikut: (1) jarak dari tempat tinggal Tim Pelaksana kegiatan ke lokasi mitra cukup jauh $(200 \mathrm{~km})$, sehingga memerlukan waktu perjalanan yang lama untuk sampai ke lokasi mitra, sekalipun hal ini tetap dapat diatasi dengan baik, (2) adanya tugas mengajar dan pelayanan akademik yang lain di kampus oleh Tim Pelaksana PKMS, sehingga pelaksanaan kegiatan harus disesuaikan dengan kesediaan mitra PKMS.

Sekalipun terdapat beberapa faktor penghambat dalam melakukan kegiatan, namun semuanya dapat diatasi dan tidak mengakibatkan kegiatan PKMS yang telah disepakati dengan mitra menjadi tidak lancar. Kegiatan tetap berlangsung dan tercapai sesuai dengan target dan luaran yang direncanakan.

\section{KESIMPULAN}

Berdasarkan hasil kegiatan dan evaluasi PKMS, maka dapat disimpulkan sebagai berikut: (a) motivasi masyarakat mitra cukup tinggi mengikuti penyuluhan dan pelatihan sampai selesai, (2) materi pelatihan membuat konstruksi tempat cuci dapur dan drainase pada rumah panggung ini sangat direspon oleh masyarakat, karena pembuatannya sangat mudah dan materialnya mudah didapatkan di lokasi kegiatan, (3) secara teknis konstruksi tempat cuci dapur dan drainase pada rumah panggung ini dapat diterima, dimengerti, dan ditiru oleh masyarakat mitra terutama dalam proses pembuatannya, (4) masyarakat mitra bersedia membuat konstruksi tempat cuci dapur dan drainae pada rumahnya masing-masing dan menyampaikan kepada masyarakat lainnya.

\section{DAFTAR PUSTAKA}

Hartono Purbo. (1988). Utilitas Bangunan. Jakarta: Djambatan Sarwono, S.W. 1992. Psikologi Lingkungan. Jakarta: Grasindo.

Soerjani, dkk. 1987. Lingkungan : Sumber Daya Alam dan Kependudukan dalam Pembangunan. Jakarta : Djambatan. Soemarwoto, O. 1985. Ekologi Lingkungan Hidup dan Pembangunan. Jakarta: Fakultas Ekonomi Universitas Indonesia.

Tjiptoherianto, P. 1989. Pembangunan Sumber Daya Manusia. Jakarta: Fakultas Ekonomi Univesitas Indonesia Asrib, A. R., \& Arfandi, A. (2019). Perumahan Tamarunang dalam memelihara drainase lingkungan. Seminar Nasional Pengabdian Kepada Masyarakat, 2018(2). 